\title{
Challenging the food vs. fuel dilemma: Genealogical analysis of the biofuel discourse pursued by international organizations
}

\author{
Magdalena Kuchler and Björn-Ola Linnér
}

\section{Linköping University Post Print}

N.B.: When citing this work, cite the original article.

Original Publication:

Magdalena Kuchler and Björn-Ola Linnér, Challenging the food vs. fuel dilemma: Genealogical analysis of the biofuel discourse pursued by international organizations, 2012, Food Policy, (37), 5, 581-588.

http://dx.doi.org/10.1016/j.foodpol.2012.06.005

Copyright: Elsevier http://www.elsevier.com/

Postprint available at: Linköping University Electronic Press http://urn.kb.se/resolve?urn=urn:nbn:se:liu:diva-80821 


\section{ABSTRACT}

This paper looks critically at how food and agriculture-, energy security-, and climate changeoriented international organizations have consolidated and modified the biofuel discourse in relation to the agricultural system. Using Foucault-based genealogical analysis of discursive formations, the paper traces the last twenty years of institutions' biofuel debate in relation to rural production. We find that the prevalent motive is an aspiration to combine the agriculture and energy markets into one, which prompts structural changes and challenges in the rural sector. This has implications for the future role and shape of global agriculture and - contrary to the food vs. fuel perspective - calls for re-conceptualizing the biofuel debate as the food vs. food dilemma.

\section{KEYWORDS}

biofuels, bioenergy, food, agriculture, energy, discourse

\section{Introduction}

An unprecedented push for biofuels and a massive increase in energy production from rural feedstocks has raised a "food vs. fuel" debate. This highly controversial dilemma is not new to the international agenda, but constitutes a bone of contention in the ongoing discussion of bioenergy. The issue of "turning food for the poor into fuel for the rich" (Kovarik, 1998) was raised by the opponents of ethyl fuel alcohol as early as the beginning of the twentieth century. Over the past decade, due to rising oil prices and climate change concerns, the biofuel discussion returned to the international agenda (Brenton et al., 2010; Kovarik, 1998). Particularly in recent years, serious fluctuations in global food prices have added more fuel to 
the fire and has strongly polarized the actors involved in deliberations on the issue. However, when we examine this debate more closely, we see that it has evolved from the grain vs. gas conflict, and is also strongly driven by the concept of combining both the agriculture and energy markets, which requires the expansion and intensification of agricultural production, prompting structural change and serious challenges in the sector.

This article aims to parse and scrutinize how the biofuel discourse has been consolidated and modified in relation to the agricultural system. Specifically we look at three major international organizations (IOs) focused on food and agriculture, energy, and climate: the United Nations Food and Agriculture Organization (FAO), the International Energy Agency (IEA), and the Intergovernmental Panel on Climate Change (IPCC). These organisations are by no means the only ones important for the biofuel discourse. We selected them as representing three key areas in the discussion on biofuel: food and agriculture, energy, and climate.Our study builds on a Foucault-based genealogical analysis of the discursive formations of the biofuel-agriculture juxtaposition within the discussions, recommendations, and policy options pursued and advanced over the last twenty years by these three international organizations.

While the debate has involved many pro and con arguments from multiple points of view articulated by many actors, it constitutes a concatenation of the three highly problematic issues of agricultural production, energy security, and climate change mitigation. We selected three international organizations that, by their mandates, focus on these issues from various angles. The Food and Agriculture Organization of the United Nations (FAO) is a specialized body designed to lead international efforts to improve food security in the world. This institution provides a platform for a global agenda for agricultural production, rural development, and food security. The International Energy Agency (IEA) is concerned with options and responses regarding global energy security challenges. Established by a group of 
high-income countries, the Agency can influence international energy markets and industries (Podobnik, 2006). The International Panel on Climate Change (IPCC) plays a prominent role in formulating climate policy, as a consultative scientific body that is indirectly prescriptive via proposing various mitigation and adaptation options.

Despite these three organizations having their own objectives and tasks, their agendas include discussions of energy production from biomass and of the role and purpose of global agriculture. Moreover, these organizations are capable of influencing international policies through their persuasive recommendations and expert appraisals. Against this background, their advocacy gives a partial representation of the broader context in which the biofuel discourse is situated, while nevertheless illuminating specific trends that allow us to provide an alternative view beyond the strongly polarized food vs. fuel debate.

The choice of studied international organizations is also a determinant of the twentyyear span, because, within this timeframe, the selected global institutions have been actively participating in the biofuel discussion. While the twenty-year limit of the study does not allow us to go back further in time and trace the formation of earlier discursive articulations, our analytical case is suspended at a specific moment when, due to the global deployment of the biofuel option on a large scale, the debate is particularly vivid and rich in discursive trajectories.

The paper is structured as follows. In Section 2, we present genealogy as our analytical approach. In Section 3, we explain our data collection and processing. In section 4, the findings are discussed. Finally, the conclusions are presented in Section 5.

\section{Analytical approach: genealogical analysis}

Introduced by Friedrich Nietzsche (Leiter, 2002; Nietzsche, 1997) and developed by Michel Foucault (Foucault, 1984), genealogical analysis is a specific mode of historical investigation 
that aims to trace and parse conceptual processes (Bleiker, 2000; Devetak, 2005). As an analytical tool, genealogical analysis provides "a processual perspective on the web of discourse" (Bevis et al., 1993, p. 194), its purpose being not to describe actual events, but to present a history of the present designed to outline the conflicts and strategies of control that condition discursive formations (Andersen, 2003; Dreyfus and Rabinow, 1983; Prado, 2000).

The motive for this analytical approach "is to maintain passing events in their proper dispersion; it is to identify the accidents, the minute deviations - or conversely, the complete reversals - the errors, the false appraisals, and the faulty calculations that gave birth to those things that continue to exist and have value for us" (Foucault, 1984, p. 81). Hence, in Foucault's application of genealogy, it is not the meaning itself of a statement or what lies hidden behind it that is interesting, but "the rules of formation that determine the objects, concepts, operations and options of a particular discourse" (Torfing, 1999, p. 90). According to Foucault (1984), "genealogy is gray, meticulous and patiently documentary"; it "operates on a field of entangled and confused parchments" and thus "requires patience and a knowledge of details" (p. 76). Specifically, genealogical analysis approaches dispersed texts and chains of thought in an interpretative manner and thereby lets us carefully expose small fractions, minor shifts, and subtle angles in the content of the collected and extracted data.

In the present case, by providing a processual perspective, this analytical approach allows us to explore the bioenergy discourse and its relationships with agriculture not in a linear and evolving fashion, but in a way that reveals the cross-section of the genealogical tree in the form of various discursive processes. In the framings advanced by the identified organizations, the examined debate undergoes various trajectories of modification and adjustment. Hence, the critical operation of genealogical analysis as applied here attempts to reveal the discords and constraints in these trajectories that transform or modify the discursive formation in an attempt to control the uncontrollable. However, these processual 
movements are of greater or lesser duration, and may be discontinuous, intermittent, and dispersed. This is why passing events are here maintained through genealogy; a chronological/historical approach or institutional analysis would be unsuitable for unmasking certain important aspects of the discursive formation that we present in the “Analysis" section.

Apart from the food crisis, which had its specific temporal momentum, it is not factual time that guides our analysis. The process of disentangling and elucidating the changes in the institutional debate has a different basis. Following Foucault's criteria of formation, transformation, and correlation (1991), we distinguish three layers in the genealogy of the biofuel discourse. In the first step, we identify the discursive core and how its consolidation takes place by applying a collection of solidifying arguments. In the second step, by tracing the transformation of the discursive formation as it occurs at various moments and as it prompts changes in specific directions, we investigate the modification of the discursive formation, in which discrepancies and deviations are addressed to protect the core's logic. Finally, in the third step, we identify discontinuities, in which the logic of the discursive core cannot be maintained, causing cracks and dislocations in the formation due to the pressure of new challenges.

We perform a textual analysis by approaching dispersed "parchments" and chains of thought in the interpretative manner fostered by the genealogical approach and according to which we focus on bioenergy perceived as a conceptual entity formed and advanced as a carrier of specific meanings for political or economic reasons. In this sense, our analysis does not go beyond the scope of the text and our meticulous documentation is based on empirical data in the form of documents, reports, and other papers issued by the selected organizations. However, the process of forming and reshaping the meaning creates specific correlations that situate a discursive formation in relation to other discourses and in relation to the external 
context in which all the discourses function. In our case, we consider how the biofuel discourse is related to that of agriculture (Der Derian, 1987; Foucault, 1991).

\section{Collecting and processing the empirical data}

The empirical data were collected and distilled in two steps. First, the primary data covering the 1990-2010 period were collected from the websites and online databases of FAO (http://www.fao.org), IEA (http://www.iea.org), and IPCC (http://www.ipcc.ch) using the following search terms: "agrofuel”, “agroenergy”, “biofuel”, “bioenergy”, “biomass energy”, “biomass fuel”, “biodiesel”, "biogas”, “ethanol”, “energy crop”, “energy plantation”, “firstgeneration", and "second-generation". In the first round of data collection, the research field was not restricted to a particular type of biomass energy, because that would yield a partial image of the discursive formation and its transformation in discussions advanced by selected IOs. The empirical data gathered from the IPCC database was the weakest, because the Panel publishes its scientific reports and assessments infrequently and has only recently become increasingly active in discussing bioenergy.

As a second step, we narrowed down the material to texts dealing with agricultural or rural aspects of biofuel. To extract the specified context, reports and documents issued by FAO, IEA, and IPCC were further searched using the following terms: "agriculture", “agricultural", “crop", “cultivate", “cultivation", "farm", “feedstock”, “food", "land”, "plantation", "rural”, "subsidies", "supply”, and "surplus". The entire process of collecting and distilling the empirical data was implemented chronologically.

Documents were searched to extract and distil the empirical data which were later examined from a theoretical perspective that facilitates observation and helps develop the line of reasoning presented in the analytical section. Text searching was necessary because each selected institution advances the bioenergy concept in relation to agriculture in a 
different textual fashion. In other words, for example, some documents are entirely devoted to biofuel production in a rural context, while others also include, among many other issues concerning biomass-derived energy, long and short sections or fragments that had to be extracted instead of covering the whole content of various papers for the analysis.

\section{Analysis}

In the following section, we will structure our analysis according to three layers of the biofuel discourse: the consolidation and modification of the discourse, as well as discontinuities within it.

\subsection{Consolidation of the biofuel discourse}

The formation of the contemporary biofuel discourse advanced by the three organizations is rooted in and built on the concept of synthesizing the agriculture and energy markets (Ammerer et al., 2003; Domac et al., 2005; FAO, 1992, 2003, 2005, 2007a,b, 2008a,d,f,g,j,1,k, 2009a,c,f; FAO/GBEP, 2007; Flammini, 2008; IEA, 1994, 1997a,b, 1999, 2001a, 2004a; IEA Bioenergy, 2004, 2008b; IPCC, 2001a,b, 2007b; Mabee et al., 2004; OECD/FAO, 2007; OECD/IEA, 2007; WEC/FAO, 1999). The amalgamation of these domains meets the basic criterion for the core of a discursive formation. When the institutions propose the idea of combining food and energy production through integrating both into one scheme, this is not an expression of the awareness that agriculture depends greatly on energy, nor an introductory description of how biofuels are actually produced and derived thanks to rural practices.

To illustrate this, for example FAO argues that "a more integrated approach has to dominate the outlook of energy and food as one plan" (FAO, 1992, p. 125) and that such an approach would yield benefits in the form of increased food and bioenergy production (FAO, 
1994, p. ii). According to IEA, "the use of biofuels allows countries the opportunity to synthesize agricultural and energy policies" (IEA, 1997b, p. 43), while IPCC suggests the linking of policies governing agriculture and energy sectors in order to mitigate climate change (IPCC, 2001b, p. 26). As can be observed, each of the institutions articulates an assertion of the desired opportunity, a configuration in which food and fuel are produced simultaneously by the same sector.

Furthermore, however, to strengthen the concept of biofuel production that constitutes the discursive core, based on the incorporation of agriculture and energy, its formation is confirmed in three particular ways: argumentation for why both markets should be integrated; assurances of feasibility concerning where and how the integration could take place; and conceptual consolidation.

First, the desirability of such integration is justified by citing a combination of multiple macro socio-economic benefits. The usually cited and continually emphasized benefits of the biofuel strategy are rural employment, either by creating new or sustaining current jobs, generating income, and alleviating poverty, or by contributing to and enhancing the revitalization of agricultural sectors around the world (Cohen et al., 2008; FAO, 1994, 2005, 2007a,b,c, 2008a,b,c,f,g,i,k, 2009b,d,f; FAO/GBEP, 2007, 2008; IEA, 1994, 2004a, 2008a; IEA Bioenergy, 2004, 2006a, 2008b,d; IPCC, 1995a,b,c, 2001a, 2007b; Jürgens et al., 2004; Mabee et al., 2004; Mabee and Saddler, 2005, 2006; Müller et al., 2007; OECD/FAO, 2008; OECD/IEA, 2007; Walter et al., 2007). These institutions base their argumentation on the assumption that producing energy from biomass could counter the decreasing trend in real commodity prices that has depressed rural development. This would make this stagnant sector attractive once again, help create new market opportunities, and capture the new investments necessary to push agricultural growth forward (FAO, 2008a,b,c,k, 2009f; IEA, 1994, 2004a, 2006a,c; IEA Bioenergy, 2004, 2006a, 2008d; IPCC, 2007b; Mabee et al., 2004; OECD/IEA, 
2007; Walter et al., 2007).

In FAO documents, processing biomass for energy is said to provide significant levels of financially beneficial rural employment that generates substantial income (Cohen et al., 2008; FAO, 1994, 2007a,b, 2008b,k, 2009b,d; FAO/GBEP, 2007, 2008). According to the Organization, "biofuels can be instrumental in bringing an agricultural renaissance that revitalizes land use and livelihoods in rural areas" (FAO, 2008b, p. 1) providing "new economic opportunities for the 2.5 billion people who depend on agriculture for their livelihoods" (FAO, 2008a, p. 4). A common argument made in IEA reports is that fuels produced from biomass can become tools for economic development by helping create and maintain agricultural jobs and by increasing farmers' incomes (Domac et al., 2005; IEA, 1994, 2002, 2004a, 2008a; IEA Bioenergy, 2006a; Mabee et al., 2004; Mabee and Saddler, 2005; OECD/IEA, 2007). The Agency states that "production of biofuels from crops such as corn and wheat (for ethanol) and soy and rape (for biodiesel) provides new product market opportunities for farmers, with the potential to increase farming revenues or expand the productive capacity of existing cropland" (IEA, 2004a, p. 176), bringing economic benefits to rural communities (IEA, 2004a, p. 14). Three IPCC assessment reports claim that bioenergy production in developing countries could be economically beneficial by offering prospects of increasing rural employment and income (IPCC, 1995a,b, 2001a, 2007b).

To make the macro-economic asset for biofuels stronger, various documents from these organizations attempt to solidify some of the purported benefits by conceptualizing them as necessary solutions or responses to particular pressures, such as food shortages and food surpluses. In the paper "Bioenergy and Development: Technical and Environmental Dimensions" (1994), FAO argues that "if rural communities are to prosper as a country develops then secure and financially beneficial rural employment must be a central theme" (p. 
42); thus, biofuel's potential to create significant numbers of agricultural jobs is vitally important. Moreover, the same FAO report suggests that a substantial increase in crop yields is required to meet rising global food demand, and that "modern biofuel technologies may aid developing country farmers to increase food crop yields at a faster rate than population growth" (FAO, 1994, p. 2). According to this logic, if the world's increasing population is to be fed, not only must yields continue to increase, but energy production as well, so the supply of biomass energy feedstock could help improve the situation on both fronts (FAO, 1994, 2007b, 2008b,k). Similar arguments are made in IEA reports. Since industrial countries face the chronic problem of high production levels, the biofuel option can effectively respond to the pressure of surpluses and thus maintain agricultural land in production, additionally creating rural employment and increasing demand for domestic agricultural products (IEA, 1994, 1998, 2004a). Bioenergy is conceptualized not just as an opportunity that provides various benefits, but as an indispensable prerequisite that furthermore confers significance and longevity on the backbone of the discursive formation.

Second, apart from the argumentation regarding the benefits and preventive measures that strengthen the core conceptualization, it is also necessary to provide assurances as to the feasibility regarding where and how the implementation should take place.

The question of where refers to the availability of land required for producing biofuels, for which it is crucial to allocate and assure sufficient rural acreage for feedstock cultivation, which would also reduce the competition with food production. The most often mentioned areas allocated for biofuel production that would also have a potential to minimize the risk of competition with other rural outputs in the form of food and feed are: "set-aside" (Bolter et al., 2007; FAO, 1994; IEA, 1994, 2004a, 2006c; IEA Bioenergy, 2004; IPCC, 2001a, 2007b) or "surplus" land (Heinimö et al., 2007; IEA, 2008a; IEA Bioenergy, 2008b; IPCC, 2001a, 2007b; OECD/IEA, 2007) in industrialized countries, as well as "marginal" (Cohen et al., 
2008; FAO, 1994, 2005, 2007b, 2008f,g, 2009e; FAO/GBEP, 2007; Heinimö et al., 2007; IEA, 2004a, 2006c, 2008a,b; IEA Bioenergy, 2005, 2008b; IPCC, 2001a, 2007b; OECD/IEA, 2007), “degraded" (Cohen et al., 2008; FAO, 1994, 2005; FAO/GBEP, 2007; IEA, 1997a, 2008a,b; IEA Bioenergy, 2005, 2006a, 2008b; IPCC, 2001a,b, 2007b; OECD/IEA, 2007), or “abandoned" (IEA Bioenergy, 2006a, 2008b, 2009b; IPCC, 2007a) lands located mostly in developing nations. While the "set-aside" term is introduced and defined in the political measures pursued by developed countries, it is unclear what the terms "marginal", "degraded", and "abandoned" actually stand for, because they are usually not defined or practically exemplified by the institutions proposing such locations as suitable for reducing competition with food and feed outputs. Still, various areal definitions seem to be carefully spelled out in the IOs' documents in order to forestall potential controversies regarding competition from other uses of biomass. How to cultivate and produce biomass for energy so as to limit competition with other rural outputs also matters. It is recommended that biofuel initiatives should be undertaken with careful planning and efficient management, under specific conditions and with the proper assessment of resources and incentives (Cohen et al., 2008; FAO, 1994, 2008c,h,k, 2009d; IEA, 1998, 2006c, 2008a,b; IEA Bioenergy, 2006a, 2008b, 2009a; IPCC, 2007b; OECD/IEA, 2007).

Third, the core concept of combining agriculture and energy markets is also grounded and solidified by anchoring it in specific terminologies that mark the conceptualization of a market opportunity leading to further diversification of end-use products and the increased multi-functionality of rural production by using crops for various purposes (FAO, 2008a,f,k; IEA, 1997a, 1999, 2001b; IPCC, 2007a; Müller et al., 2007; OECD/IEA, 2007). The continuous use of the terms "energy crop" (Bolter et al., 2007; Cohen et al., 2008; FAO, 1992, 1994, 2004, 2005, 2007b, 2008f,g,i,j; FAO/GBEP, 2007; Flammini, 2008; Heinimö et 
al., 2007; IEA, 1994, 1997a,b, 1998, 2001b, 2004a, 2006a,c, 2008a,b; IEA Bioenergy, 2004, 2005, 2006a, 2007a, 2008b,d; IPCC, 2001,a,b, 2007a,b; Mabee and Saddler, 2005; OECD/IEA, 2007) and “energy plantation” (FAO, 1994, 2005, 2008f,g,k, 2009e; FAO/GBEP, 2007; IEA 1997b, 2001b, 2004a,b; IEA Bioenergy, 1998; IPCC, 2007a,b,c; WEC/FAO, 1999), which refer to both food and non-food feedstocks, signifies a new type of commodity for a different end use, and a practice with a different output and function from those of traditionally prevalent rural products in the form of food, feed, and fibre.

At the same time, while "energy crop" and "energy plantation" smoothly camouflage an association with cultivation processes designed for food and feed, they can also circumvent a realization that, in fact, the conventional agricultural production of biomass for consumption can be at any time diverted for energy processing. As FAO states, "from the point of view of an individual farmer, it is unimportant what end use a prospective buyer has in mind for the crop" (FAO, 2008k, p. 23), because the choice of feedstocks depends on market prices, net revenues, and risk calculations, making the decision to cultivate an energy crop the same as for any other crop (FAO, 2008f,k). Nevertheless, in the deliberations of the IOs, the term "energy crop" is not limited to non-food feedstocks, but also encompasses commodities traditionally considered as food (FAO, 1994, 2004, 2008a,j,k,m, 2009a; FAO/GBEP, 2007; Flammini, 2008; IEA, 1994, 1999, 2004a; IEA Bioenergy, 2007a, 2009a; IPCC, 2007a; OECD/FAO, 2006; OECD/IEA, 2007). Furthermore, "energy crops” and "energy plantations" are not just established and cultivated for no reason or without a commitment, regardless of their food or non-food function. Their destination is strictly prescribed and their value signified by additional terms such as "dedicated" (FAO, 1994, 2008g; FAO/GBEP, 2007; IEA, 1997b, 2004a, 2006a, 2008a; IEA Bioenergy, 2005, 2006a, 2009a; IPCC, 2001b, 2007a,b; Mabee and Saddler, 2005) and "purpose grown" (FAO, 2009e; IEA, 2008b; IEA Bioenergy, 2008d, 2009a; IPCC, 2007b; OECD/IEA, 2007; WEC/FAO, 1999). The end result 
is justification for the development of crops and plantations specifically for energy, even though their conventional roles in the agricultural market may differ.

\subsection{Modification of the biofuel discourse}

Two complementary motives lead to particular modifications being made to the discursive formation via discussions and recommendations proposed by the three IOs.

The first motive is the realization that the industrialized countries' natural conditions limit potential production increases there, so they will be unable to meet the demand set by specific national and regional targets to increase the proportion of biofuels in their energy mix. The second problem, partially a consequence of the first, is the industrialized world's comprehension of high cost pressures associated with cultivating and processing biomass into energy sources that - if low end-prices are achieved - could successfully compete with conventional energy sources on the market. Yet the economic pressure is particularly difficult to alleviate in the situation of a declining oil price, which makes production of biomass cheaper but paradoxically leaves bioenergy with a limited amount of space to compete with fossil fuels, unless its price is artificially lowered by subsidies and other support mechanisms provided by governments. Nevertheless, the basis of the discursive formation proposed by the IOs is not explored in order to be altered, and the fusion of the agriculture and energy markets is neither questioned nor scrutinized. Instead, the recently formed biofuel discourse is converted by applying modified structures and façades in the form of specific adjustments and supports that would aim to stabilize the dubious construct of the core conceptual arrangement.

To combat land and climatic constraints, and simultaneously alleviate economic pressure by lowering the cost of production, several IO reports suggest that expanding agriculture through increasing crop yields, large-scale cultivation, and technological developments is required (FAO, 2006, 2008b,d,j,k; FAO/GBEP, 2007; IEA, 1997a, 1998, 
1999, 2001a,b, 2003, 2004a, 2006c; IEA Bioenergy, 2008b; IPCC, 2007b; OECD/IEA, 2007). This notion is clearly entrenched in a strong conviction that the continuous aggregation and advance of global rural production is possible, so a message of assurance is advanced that it is highly possible to extract an even greater biomass output for energy, while maintaining the same level of yields for food and feed (FAO, 2008b,j; IEA, 1997a, 2004a, 2006c; IEA Bioenergy, 2008b; IPCC, 2007a,b; OECD/IEA, 2007). For example, the intensification of cultivation methods, various improvements in farmland management and efficiency, modern feedstock breeding, and technological innovations such as the introduction of genetically modified (energy) crops are proposed as potential responses to natural and spatial constraints and to the challenge of cost-effectiveness.

As early as 1999, IEA deliberated on whether the necessary acreage was available to cultivate biomass for energy and, while admitting that land was indeed a strong constraint, it suggested that "a significant increase in yields would increase biofuels' chances" (IEA, 1999, p. 75). Moreover, the Agency argued that "the key issues for biofuels involve developing new feedstocks and production processes, determining land requirements and availability, and lowering costs ... For biofuels to play a bigger role, substantial improvements in biofuel production technologies (with greater yields) or changes to land use will be necessary" (IEA, 2003, p. 9). In 2004, the institution stipulated that "one way to increase the benefits and lower the costs of producing biofuels is to raise crop yields ... Although traditional methods like selective breeding continue to play the main role in improving crop yields, biotechnology offers an important new approach, particularly in the mid to long term” (IEA, 2004a, p. 47). Using much the same line of reasoning, in 2007 IEA claimed that "in the future it could be that genetically modified energy crops can be produced that will be more efficient solar energy collectors ... and therefore be higher yielding but also require lower inputs of fertilisers, have greater resistance to pest and disease, and be dry land tolerant. If such an ideal 
new crop is ever produced the potential for biomass as an energy source would increase significantly" (OECD/IEA, 2007, p. 25). In a similar tone, FAO argues that "the degree of competition between energy crops and food and fodder production would depend, among other things, on progress in crop yields, livestock feeding efficiency and bioenergy conversion technologies" (FAO, 2007a, p. 11). According to the Organization, "the increased demand for biofuels can be met, on one hand, by technical improvements in production: more efficient processing and higher yields of feedstocks per unit area ... Even for first-generation biofuels, more intensive land use, producing higher yields, could meet a proportion of the increased demand for feedstocks" (FAO, 2008b, p. 11). IPCC states that "in the years to come, some biofuels may become economically competitive, as the result of increased biomass yields, developments of plants that are better suited to energy production, improved cellulosic conversion processes and even entirely new energy crops and conversion processes" (IPCC, 2007b, p. 344). The visions of conceivably limitless intensification of rural production, highly efficient farming management, indispensable technological developments and improvements, ideal new crops and so forth advanced by the institutions illustrate the magnitude of changes that would have to be applied to the current global rural systems to expand biomass production substantially.

Concomitant with such reasoning is the parallel realization advanced by these organizations that intensifying global agricultural production to meet growing biomass demand, while managing natural constraints and, in particular, lowering costs, entails expansion to vast areas of the global South and the establishment of international trade necessary to reap maximum efficiency. It is often argued in the documents issued by these IOs that developing countries are better suited for biomass production for energy needs because they possess more suitable conditions in the form of abundant and inexpensive land resources, cheap labour, and favourable climate (FAO, 1994, 2007b, 2008a,k; FAO/GBEP, 
2007; IEA, 2004a,b, 2006b,c, 2008b; IEA Bioenergy, 2005, 2006a, 2008c, 2009a; IPCC, 2007b; Müller et al., 2007; Walter et al., 2007).

According to FAO, "several developing countries - with land to devote to biomass production, a favourable climate to grow them, and low-cost farm labour - are well placed to become efficient producers" (FAO/GBEP, 2007, p. 53). In its 2008 State of Food and Agriculture report, the Organization suggests that "many of the world's poorest countries are well placed, in agro-ecological terms, to become major producers of biomass for liquid biofuel production - or to respond in general to higher agricultural prices" (FAO, 2008k, p.

79), and that "private investors interested in developing biofuel feedstock production in developing countries will look to the establishment of plantations to ensure security of supply" (FAO, 2008k, p. 86). Similarly, IEA states that "at least in the near term, the costs of producing biofuels are much lower in tropical and subtropical countries - especially developing countries with low land and labour costs - than in developed, temperate countries" (IEA, 2004a, pp. 15-16). Furthermore, the Agency argues that "given the availability of land and relatively low costs of labour in many developing countries, biomass production costs can be low, and thus offer an opportunity to export biomass-based energy carriers to developed countries. The opportunity to export biomass derived fuels in the form of commodities for the world's energy markets can provide a stable and reliable demand for produced fuel from rural communities particularly in many developing countries, thus creating an important incentive and market access in many areas in the world" (IEA Bioenergy, 2006a, p. 3). In its 2007 report, IPCC names Latin America, Sub-Saharan Africa, Eastern Europe, and Oceania as key regions for the successful introduction of bioenergy production (IPCC, 2007b, p. 629), with additional contributions from East and Northeast Asia (IPCC, 2007b, p. 511).

However, intensifying and expanding agricultural production to meet the global biofuel demand and ensure a substantial biomass supply not only puts pressure on land and resources, 
but also triggers competition between various outputs and, due to crop price correlation affecting the entire global agricultural market, induces a price-increasing effect on commodities in general (FAO, 2008a,f,k; Flammini, 2008; IEA, 2004a; IEA Bioenergy, 2008a,d; OECD/FAO, 2007). Consequently, market prices for biofuel feedstocks rise as well and, while this could mean better income and investment incentives for farmers, it also implies more expensive bioenergy production, contradicting efforts to alleviate cost pressures. Thus, to make biofuel production cheaper again and reduce the feedstock cost factor, the IOs suggest applying the very same remedies in the form of intensifying and expanding biomass cultivation that were proposed in the first place to consolidate the discursive core (Cohen et al., 2008; FAO, 2008d,k, 2009f; Flammini, 2008; IEA, 2001b, 2004a, 2006c, 2007; IEA Bioenergy, 2008b; Walter et al., 2007). In other words, not only must global agriculture intensify its production and expand its acreage because of the initial demand for biofuels, but now it must reinforce its efforts due to higher crop prices triggered by the diversification of land and resources allocation for other purposes than food, feed, or fibre.

Facing such circumstances, the IOs admit that the benefits of bioenergy projects will not be spread equally, favouring farmers who produce greater surpluses and have better access to land and resources, while poorer smallholders and agricultural labourers will stand to lose (FAO, 2008b,f,k, 2009b; IEA Bioenergy, 2006a; Walter et al., 2007). Several reports identify three reasons for this.

First, intensification and expansion - necessary to meet rising demand and ensure the security of cheap biofuel supply - require large-scale projects that, according to the IOs, can provide substantial biomass production potential and cost reductions, as well as incentive for investments (FAO, 1994, 2008a,e,g,k; Heinimö et al., 2007; IEA, 2004a, 2006c, p. 45; IPCC, 2007b). Simultaneously, however, large-scale schemes increase the mechanization of feedstock harvesting and the automation of biomass processing, reducing the size of the 
manual workforce and the extent of rural employment (FAO, 2008a,b,f,g, 2009b; IEA Bioenergy, 2006a; IPCC, 2007b; OECD/IEA, 2007; Walter et al., 2007). Second, large-scale plantations imply mono-cropping, which depends greatly on using artificial fertilizers, pesticides, and various biotechnologies. The end result is greater dependence on external inputs and the exclusion of less resourceful farmers who lack access to the capital and technology needed to intensify agricultural production (FAO, 2008g, 2009b; IEA, 1997a). Third, large-scale systems induce significant concentration of land ownership, which tends to violate land property rights, particularly of smallholder farmers in the developing world, causing major displacements of rural communities and making it unclear how they could participate in and particularly benefit from bioenergy schemes (FAO, 2009b; FAO/GBEP, 2007; IEA Bioenergy, 2006a).

When it becomes clear that not all farmers and rural communities would be positively affected by the structural changes in the global agricultural system wrought by increased biofuel production, the IOs try to adjust their contradictory trajectories. In response, the organizations propose highly vague recommendations regarding proper management that could include pro-poor policies (Cohen et al., 2008; FAO, 2008d; IEA, 2008a; IEA Bioenergy, 2006a; IPCC, 2007b) as well as assurances of clearly defined rights to food and land ownership (FAO, 2007b, 2008a,b,k; IEA, 2008a; IEA Bioenergy, 2008d). In particular, FAO acknowledges the importance of involving smallholder farmers and local communities in bioenergy projects and production chains, and of strengthening their participation through contract farming and co-management (Cohen et al., 2008; FAO, 2008g,h,i). Simultaneously, however, FAO admits that "developing biofuel systems that will truly satisfy local needs, and contribute to poverty reduction and food security is a complex challenge, usually follows an iterative path, and takes time" (FAO, 2008h, p. 19). The attempts to modify the discourse to preserve its core ideas, however, were challenged by the 2007 food price crises. 


\subsection{Ricochet: discontinuity induced by global food prices}

In its 2007 State of Food and Agriculture report, FAO explains that it remains unclear whether the strong increase in agricultural commodity prices, experienced globally the same year, "signals a new paradigm for agricultural prices and, if so, what that might mean for agricultural development, poverty reduction and food security" (FAO, 2007d, p. 119). A similar tone of uncertainty and confusion is evident in other documents issued by both FAO and IEA during the world food price crisis of 2007-2008 and in successive years (FAO,

2007a,d, 2008h,k, 2009b,c; FAO/GBEP, 2007, 2008; Heinimö et al., 2007; IEA, 2008a,b; IEA Bioenergy, 2008b,d; Müller et al., 2007; OECD/FAO, 2008). IPCC's latest assessment report, released in 2007, does not encompass that particular period, so the Panel's role will be omitted from this part of the analysis. The escalation of commodity prices had a major impact on the discursive formation advanced by the institutions, which now found it difficult to determine whether the global agricultural market and consequently food security were affected by increased biofuel demand and to what extent it could trigger the event. Therefore, both FAO and IEA attempted to recalibrate their stances on bioenergy in relation to agricultural practices by adjusting their arguments to the phenomenon of skyrocketing food prices. Again, the organizations have been so persistent in advancing the discursive core that the process of its solidification has not been seriously scrutinized; instead, the discursive trajectory has strongly ricocheted off the crucial food price rise, turning instead to discussing an unknown future, leaving present circumstances without critical examination.

FAO has attempted to explain away the impact of biofuel demand on the global agricultural market by making a "time-scale" argument, which allows the establishment of a contrast between current circumstances and future developments. The Organization argues that, in the short term, higher commodity prices could reduce the food supply and negatively affect the purchasing power of net food buyers and poor households (FAO, 2007a, 2008f,k, 
2009f). It pinpoints a rapidly growing demand for biofuel feedstock as posing an immediate threat to food security (FAO, 2008k, p. 8). Thus, FAO describes the food price crisis as a temporary phenomenon in order to contrast it with potentially positive future developments, by suggesting that, in the long term, increased biomass demand and prices may actually serve as an engine of agricultural growth, boosting opportunities for rural communities (FAO,

2008f,k, 2009f). The institution argues that, in the medium-to-long term, "there could be a positive supply response not only from smallholders who are net sellers but also from those on the margin and those who are net buyers who are able to react to the price incentives" (FAO, 2008k, p. 79). However, while the contention is similar to that advanced by FAO to solidify and strengthen the discursive core of biofuel production, rooted in the synergy of agriculture-energy markets, this time the difference is that the "long-term" claim cannot be verified in the present, because it does not describe past and current events, but rather attempts to predict the future and, therefore, represents nothing more than speculation with a high level of uncertainty (FAO, 2008k; Müller et al., 2007).

IEA expresses concern that biofuel production boosting demand for specific crops might adversely affect food availability and that, while high food prices could be good for farmers, their impact on consumers is negative (IEA, 2008a,b; IEA Bioenergy, 2005). Simultaneously, the Agency argues that the reasons behind the increase in food prices are many and complex, and that there is no consensus yet as to how much can be attributed to the biofuel boom (IEA, 2008a,b; IEA Bioenergy, 2009b). Moreover, in light of agricultural market distortion, IEA admits that the impact of large-scale biofuel production on food prices has not been sufficiently studied (IEA Bioenergy, 2008b), so it recognizes the importance of global food demand, but only because it competes with biofuels and limits their potential (Bolter et al., 2007; IEA, 2006c, 2007; IEA Bioenergy, 2008b), not the other way 
around. However, apart from increasing the focus on potential restrictions to bioenergy production, the negative food security implications are discussed by the Agency particularly in connection with second- generation biofuels. The Agency identified the opportunity and potential of cellulosic biomass energy before the 2007-2008 crisis (IEA, 2004a,b,c; IEA Bioenergy, 2004, 2006b; Mabee and Saddler, 2005, 2006), and was highly supportive of the advanced bioenergy option in response to the impact of high food prices in subsequent years (IEA, 2006c, 2008a; IEA Bioenergy, 2007b, 2008b,c, 2009a).

The difference between these two periods is that, in the latter, IEA has used the food security issue to establish a strong contrast between the first- and second-generation options. Conventional biofuels are blamed for diverting crops, land, and resources, and for contributing to the increases in world food prices, while more advanced cellulose-based fuels are praised for providing access to a much wider range of potential feedstocks and areas available for cultivation, which could help reduce competition with other agricultural outputs and mitigate food insecurity (IEA, 2006c, 2008a; IEA Bioenergy, 2007b, 2008b,c, 2009a). However, the second-generation option still awaits implementation and commercialization, which could happen at some point in the future, though the precise timing, cannot be specified. Therefore, it is suggested that an alternative is just around the corner, but without certainty as to when it will arrive to replace conventional biomass energy production and lift the pressure from crops, land, and resources. In the meantime, first-generation biofuels remain firmly ensconced as a temporary solution with no end of production in sight but with a continuing effect on the global agricultural system.

\section{Conclusions}

What is interesting in light of the present findings are the striking similarities in how the selected international organizations form and modify the biofuel discourse in relation to 
agriculture. This could be explained by the fact that these institutions use each other's expertise in elaborating their claims. The similarity of the arguments may reflect a policy consensus based on the mainstream notion of industrial agricultural production. We argue that this conceptual trend could be also be viewed as part of the broader context in which specific international policy options, promoting the intensification and expansion of rural production, are seen as highly desirable in order to secure the biomass supply needed to meet ambitious biofuel targets.

Most importantly, our analysis demonstrates that, for the involved international organizations, the amalgamation of the agriculture and energy markets constitutes a fundamental requirement for their biofuel discourse. This discursive core is consolidated by citing potential macro socio-economic benefits and providing assurances of the feasibility of biofuel production. However, due to the physical limitations and cost pressures experienced by developed countries, the almost complete shape of the discursive formation upheld by these institutions starts to crack under the pressure of new conflicts that collide with the applied arguments and recommendations. Modifications necessary to stabilize the discursive formation trigger a chain of consequences, implying an assemblage of serious challenges that must be taken into consideration. Therefore, various contradictory dislocations make it impossible for the constituent arguments of the IOs' biofuel discourse to achieve complete integrity. The upshot is that new alterations must be made to patch the bifurcations, while the core concept of synthesizing agriculture and energy markets under the biofuel option is not questioned by the organizations. Attempts to modify the biofuel discourse to preserve its core were particularly challenged by the $2007-2008$ food price crisis. This event radically changed the trajectory of the discursive formation by evidencing the discontinuities within it and 
directing it towards the argument of a distant future, leaving its unresolved current situation suspended in temporality.

Moreover, the whole chain reaction exposed by our analysis can be portrayed as a spiralling process of development that progressively expands and ascends from the core assumption of the discursive formation defended by ad hoc arguments that transcend agriculture by enforcing serious structural changes in the sector. The biofuel discourse pursued by the involved institutions becomes a key carrier of various policies, options, and strategies that support industrialized, market-oriented agriculture characterized by large-scale production, land ownership concentration, and various biotechnological enhancements, as well as the further "fossilization" and mechanization of rural practices. These particular trends are allowed to penetrate the agricultural sector where, in particular, they intensify and transform the essential food- and feed-production modes. This can have serious implications for the distribution and consumption of rural goods, transforming the very concept of agriculture, and, most importantly, putting enormous pressure on the livelihood security of much of the rural population worldwide. Although our analysis exposes particular trends in the further modification of production patterns and provides a partial picture of the larger problem, we argue that, quite apart from the food vs. fuel debate, it is necessary to look critically at the current development of biofuel policies from the perspective of the food vs. food dilemma. 


\section{REFERENCES}

Ammerer, A., Rathbauer, J. Wörgetter, M., 2003. Rapeseed oil as fuel for farm tractors. IEA Bioenergy Task 39, Subtask “Biodiesel”, Austria.

Andersen, N.A., 2003. Discursive Analytical Strategies. The Policy Press, Bristol, UK. Bolter, I., Bacovsky, D., Wörgetter, M., 2007. Biofuels in the European Union: An overview on the EU biofuels policy. IEA Bioenergy Task 39. IEA, Paris.

Cohen, M.J., Tirado, C., Aberman, N.-L., Thompson, B., 2008. Impact of Climate Change and Bioenergy on Nutrition. IFPRI and FAO, Rome.

Bevis, P., Cohen, M., Kendall, G., 1993. Archaeologizing genealogy: Michel Foucault and the economy of austerity. In: Gane, M., Johnson, T. (Eds.), Foucault's New Domains. Routledge, London and New York, pp. 193-215.

Brenton, H., Kovarik, W., Sklar, S., 2010. The Forbidden Fuel. University of Nebraska Press, Lincoln, NB and London.

Bleiker, R., 2000. Popular Dissent, Human Agency \& Global Politics. Cambridge University Press, Port Chester, NY.

Der Derian, J., 1987. On Diplomacy: A Genealogy of Western Estrangement. Basil Blackwell, Oxford, UK, New York, NY. 
Domac, J., Richards, K.M., Segon, V., 2005. Old fuel for modern times: Socio-economic drivers and impacts of bioenergy use. IEA Bioenergy Task 29, Croatia.

Dreyfus, H.L., Rabinow, P., 1983. Michele Foucault: Beyond Structuralism and Hermeneutics, 2nd ed. University of Chicago Press, Chicago, IL.

FAO, 1992. Biogas Processes for Sustainable Development. FAO Agricultural Services Bulletin \#95. FAO, Rome.

FAO, 1994. Bioenergy for Development: Technical and Environmental Dimensions. Prepared by Woods, J., Hall, D.O. FAO Environment and Energy Paper \#13. FAO, Rome.

FAO, 2003. The Brazilian Ethanol Programme: Impacts on World Ethanol and Sugar Markets. Prepared by Koizumi, T. Commodity Policy and Projections Service, Commodities and Trade Division. FAO, Rome.

FAO, 2004. Unified Bioenergy Terminology. FAO Forestry Department, Wood Energy Programme. FAO, Rome.

FAO, 2005. Bioenergy. Item 7 of the Provisional Agenda, Committee on Agriculture, Nineteenth Session. COAG/2005/7. FAO, Rome.

FAO, 2006. Biofuels and Commodity Markets: Palm Oil Focus. Prepared by Thoenes, P. FAO Commodities and Trade Division. FAO, Rome. 
FAO, 2007a. Assessment of the World Food Security Situation. Committee on World Food Security, Thirty-third Session. CFS:2007/2. FAO, Rome.

FAO, 2007b. Recent Trends in the Law and Policy of Bioenergy Production, Promotion and Use. Prepared by Jull, C., Redondo, P.C., Mosoti, V., Vapnek, J. FAO Legislative Study \#95. FAO Legal Office, Rome.

FAO, 2007c. Report of the 33rd Session of the Committee on World Food Security (Rome, 7 10 May 2007), Hundred and Thirty-second Session. Rome, 18-22 June 2007. CL 132/10. FAO, Rome.

FAO, 2007d. The State of Food and Agriculture: Paying Farmers for Environmental Services. FAO, Rome.

FAO, 2008a. Bioenergy, Food Security and Sustainability: Towards an International Framework. High-Level Conference on Food Security: The Challenges of Climate Change and Bioenergy. Rome, 3-5 June 2008. HLC/08/INF/3. FAO, Rome.

FAO, 2008b. Bioenergy and Land Tenure: The Implications of Biofuels for Land Tenure and Land Policy. FAO, Rome.

FAO, 2008c. Bioenergy Policy, Markets and Trade and Food Policy. Technical background document from the Expert Consultation, Rome, 18-20 February 2008. FAO, Rome. 
FAO, 2008d. Climate Change, Bioenergy and Food Security: Options for Decision Makers Identified by Expert Meetings. High-level Conference on World Food Security: The Challenges of Climate Change and Bioenergy. Rome, 3-5 June 2008. HLC/08/INF/5. FAO, Rome.

FAO, 2008e. Climate Change and Food Security in Pacific Island Countries. FAO, Rome.

FAO, 2008f. Forests and Energy: Key Issues. FAO Forestry Paper, 154. FAO, Rome.

FAO, 2008g. Gender and Equity Issues in Liquid Biofuels Production: Minimizing the Risks to Maximize the Opportunities. Prepared by Rossi, A., Lambrou, A. FAO, Rome.

FAO, 2008h. How Good Enough Biofuel Governance can Help Rural Livelihoods: Making Sure that Biofuel Development Works for Small Farmers and Communities. Prepared by Dubois, O. FAO, Rome.

FAO, 2008i. Opportunities and Challenges of Biofuel Production for Food Security and the Environment in Latin America and the Caribbean. Thirtieth Regional Conference for Latin America and the Caribbean. Brasilia, Brazil, 14-18 April 2008. LARC/08/4. FAO, Rome.

FAO, 2008j. Soaring Food Prices: Facts, Perspectives, Impacts and Actions Required. HighLevel Conference on Food Security: The Challenges of Climate Change and Bioenergy. Rome, 3-5 June 2008. HLC/08/INF/1. FAO, Rome. 
FAO, 2008k. The State of Food and Agriculture. Biofuels: Prospects, Risks and Opportunities. FAO, Rome.

FAO, 20081. The State of Food and Agriculture in Asia and the Pacific Region. FAO, Bangkok.

FAO, 2008m. The State of Food Insecurity in the World. FAO, Rome.

FAO, 2009a. Implications of Rising Energy Costs and Biofuel Production on Livestock Markets. Committee on Commodity Problems, Intergovernmental Group on Meat and Dairy Products, Twenty-second Session. Asunción, Paraguay, 6-8 May 2009. CCP: ME 09/2. FAO, Rome.

FAO, 2009b. Making Sustainable Biofuels Work for Smallholder Farmers and Rural Households: Issues and Perspectives. Prepared by Rossi, A., Lambrou Y. FAO, Rome.

FAO, 2009c. Regional State of Food and Agriculture. Twenty-ninth FAO Regional Conference for Asia and the Pacific. Agenda Item 7. Bangkok, Thailand, 26-31 March 2009. APRC/08/INF/5. FAO, Rome.

FAO, 2009d. Round Table on the Bioenergy Rush: Opportunities and Risks for Food Security, the Environment and Rural Development. Twenty-ninth FAO Regional Conference for Asia and the Pacific. Bangkok, Thailand, 26-31 March 2009. APRC/08/7. FAO, Rome. 
FAO, 2009e. Small-scale Bioenergy Initiatives: Brief Description and Preliminary Lessons on Livelihood Impacts from Case Studies in Asia, Latin America and Africa. FAO and PISCES, Rome.

FAO, 2009f. The Market and Food Security Implications of the Development of Biofuel Production. Committee on Commodity Problems, Sixty-seventh Session. Rome, 20-22 April 2009. CCP 09/6. FAO, Rome.

FAO/GBEP, 2007. A Review of the Current State of Bioenergy Development in G8 +5 Countries. FAO, Rome.

FAO/GBEP, 2008. A Review of the Current State of Bioenergy Development in G8 +5 Countries. FAO, Rome.

Flammini, A., 2008. Biofuels and the Underlying Causes of High Food Prices. FAO, Rome.

Foucault, M., 1984. Nietzsche, genealogy, history. In: Rabinow, P. (Ed.), The Foucault Reader. Penguin Books, London and New York, pp. 76-100.

Foucault, M., 1991. Politics and the study of discourse. In: Burchell, G., Gordon, C., Miller, P. (Eds.), The Foucault Effect: Studies in Governmentality. University of Chicago Press, Chicago, IL, pp. 53-72. 
Heinimö, J., Pakarinen, V., Ojanen, V., Kässi, T., 2007. International Bioenergy Trade: Scenario Study on International Biomass Market in 2020. Lappeenranta University of Technology. IEA Bioenergy Task 40. IEA, Paris.

IEA, 1994. Biofuels. Energy and Environment Policy Analysis Series. IEA, Paris.

IEA, 1997a. Biomass Energy: Key Issues and Priority Needs. Conference proceedings, 3-5 February 1997, Paris.

IEA, 1997b. Key Issues in Developing Renewables. IEA, Paris.

IEA, 1998. Biomass Energy: Data, Analysis and Trends. Conference proceedings, 23-24 March 1998, Paris.

IEA, 1999. Automotive Fuels for the Future: The Search for Alternatives. IEA, Paris.

IEA, 2001a. Saving Oil and Reducing CO2 Emissions in Transport: Options and Strategies. IEA, Paris.

IEA, 2001b. World Energy Outlook. OECD/IEA, Paris.

IEA, 2002. World Energy Outlook. OECD/IEA, Paris.

IEA, 2003. Transport Technologies and Policies for Energy Security and CO2 Reductions. IEA Energy Technology Policy \& Collaboration Papers. IEA, Paris. 
IEA, 2004a. Biofuels for Transport: An International Perspective. IEA, Paris.

IEA, 2004b. Reducing Oil Consumption in Transport: Combining Three Approaches. Prepared by Fulton, L. Office of Energy Efficiency, Technology and R\&D, International Energy Agency. IEA/EETWorking Paper, EET/2004/01. IEA, Paris.

IEA, 2004c. World Energy Outlook. OECD/IEA, Paris.

IEA, 2006a. Renewable Energy: RD\&D Priorities - Insights from IEA Technology Programmes. IEA, Paris.

IEA, 2006b. The Energy Situation in Brazil: An Overview. OECD/IEA, Paris.

IEA, 2006c. World Energy Outlook. OECD/IEA, Paris.

IEA, 2007. IEA Energy Technology Essentials. IEA, Paris.

IEA, 2008a. From 1st- to 2nd-generation Biofuel Technologies: An Overview of Current Industry and R\&D Activities. OECD/IEA, Paris.

IEA, 2008b. World Energy Outlook. OECD/IEA, Paris.

IEA Bioenergy, 2004. Biofuels for Transport. IEA Bioenergy Task 39. IEA, Paris. 
IEA Bioenergy, 2005. Options for trading bioenergy products and services. In: Schlamadinger, B., Faaij, A., Junginger, M., Woess-Gallasch, S., Daugherty, E. (Eds.), IEA Bioenergy Annual Report 2005. IEA, Paris.

IEA Bioenergy, 2006a. Opportunities and Barriers for Sustainable International Bioenergy Trade and Strategies to Overcome Them. IEA Bioenergy Task 40. IEA, Paris.

IEA Bioenergy, 2006b. Second Generation Biofuels: A Review from a Market Barrier Perspective. IEA Bioenergy Task 39, Canada.

IEA Bioenergy, 2007a. Bioenergy and Biomass Trade: Evaluation of Models' Suitability for Analysing International Trade of Biomass and Bioenergy Products. Prepared by Solberg, B., Dornburg, V., Bolkesjø, T.F, Faaij, A., Junginger, M., Trømborg, E. IEA Bioenergy, Aas and Utrecht.

IEA Bioenergy, 2007b. Sustainability of Bioenergy. Joint IEA Bioenergy Tasks 29, 38, and 40, Expert Consultation, 25-26 October 2007. Dubrovnik, Croatia.

IEA Bioenergy, 2008a. Bioenergy: The Relationship with Greenhouse Gases in Agriculture and Forestry. 16th European Biomass Conference \& Exhibition, 2-6 June 2008, Valencia, Spain. IEA Bioenergy Task 38. IEA, Paris.

IEA Bioenergy, 2008b. Biomass Assessment: Assessment of Global Biomass Potentials and Their Links to Food, Water, Biodiversity, Energy Demand and Economy. Main Report. IEA Bioenergy Task 40. IEA, Paris. 
IEA Bioenergy, 2008c. Status and Outlook for Biofuels, Other Alternative Fuels and New Vehicles. IEA Bioenergy Task 39. IEA, Paris.

IEA Bioenergy, 2008d. Synergies and Competition in Bioenergy Systems. IEA Bioenergy Task 41. IEA, Paris.

IEA Bioenergy, 2009a. 2nd generation Biofuels and Trade: An Exploratory Study. IEA Bioenergy Task 40. IEA, Paris.

IEA Bioenergy, 2009b. A Global Overview of Vegetable Oils, with Reference to Biodiesel. IEA Bioenergy Task 40. IEA, Paris.

IPCC, 1995a. IPCC Second Assessment: Climate Change 1995. Intergovernmental Panel on Climate Change, Geneva.

IPCC, 1995b. Summary for Policymakers: Scientific-Technical Analyses of Impacts, Adaptations and Mitigation of Climate Change. IPCC Working Group II, Intergovernmental Panel on Climate Change, Geneva.

IPCC, 1995c. Summary for Policymakers: The Economic and Social Dimensions of Climate Change. IPCC Working Group III, Intergovernmental Panel on Climate Change, Geneva. IPCC, 2001a. Climate Change 2001: Mitigation. In: Metz, B., Davidson, O., Swart, R., Pan, J. (Eds.), A Contribution of Working Group III to the Third Assessment Report of the Intergovernmental Panel on Climate Change. Cambridge University Press, Cambridge, UK and New York. 
IPCC, 2001b. Climate Change 2001: Synthesis Report. In: Watson, R.T. and the Core Writing Team (Eds.), A Contribution of Working Groups I, II, and III to the Third Assessment Report of the Intergovernmental Panel on Climate Change. Cambridge University Press, Cambridge, UK and New York.

IPCC, 2007a. Climate Change 2007: Impacts, Adaptation and Vulnerability. In: Parry, M.L., Canziani, O.F., Palutikof, J.P., van der Linden, P.J., Hanson, C.E. (Eds.), Contribution of Working Group II to the Fourth Assessment Report of the Intergovernmental Panel on Climate Change. Cambridge University Press, Cambridge, UK.

IPCC, 2007b. Climate Change 2007: Mitigation. In: Metz, B., Davidson, O.R., Bosch, P.R., Dave, R., Meyer, L.A. (Eds.), Contribution of Working Group III to the Fourth Assessment Report of the Intergovernmental Panel on Climate Change. Cambridge University Press, Cambridge, UK and New York.

IPCC, 2007c. Climate Change 2007: Synthesis Report. In: Core Writing Team, Pachauri, R.K., Reisinger, A. (Eds.), Contribution of Working Groups I, II and III to the Fourth Assessment Report of the Intergovernmental Panel on Climate Change. Cambridge University Press, Cambridge, UK.

Jürgens, I., Best, G., Lipper, L., 2004. Bioenergy projects for climate change mitigation: eligibility, additionality and baselines. 2nd World Conference on Biomass for Energy, Industry and Climate Protection, 10-14 May 2004, Rome, Italy. 
Kovarik, B., 1998. Henry Ford, Charles F. Kettering and the fuel of the future. Automot. Hist. Rev. 32, 7-27.

Leiter, B., 2002. Nietzsche on Morality. Routledge Philosophy Guidebooks. Routledge, London, UK.

Mabee, W.E., Gregg, D.J., Saddler, J.N., 2004. Ethanol from lignocellulosics: Views to implementation. IEA Bioenergy Task 39. IEA, Paris.

Mabee, W.E., Saddler, J.N., 2005. Ethanol from Lignocellulosics: Policy options to support bioethanol production. IEA Bioenergy Task 39. IEA, Paris.

Mabee, W.E., Saddler, J.N., 2006. Ethanol from lignocellulosics: Comparing biofuel technology options. IEA Bioenergy Task 39. IEA, Paris.

Müller, A., Schmidhuber, J., Hoogeveen, J., Steduto, P., 2007. Some insights in the effect of growing bio-energy demand on global food security and natural resources. Paper presented at the International Conference: Linkages between Energy and Water Management for Agriculture in Developing Countries, Hyderabad, India, 28-31 January 2007.

Nietzsche, F., 1997. On the Genealogy of Morality. Ansell-Pearson, K. (Ed.), Diethe C. (Transl.). Cambridge Texts in the History of Political Thought. Cambridge University Press, Cambridge, UK.

OECD/FAO, 2006. Agricultural Outlook 2006-2015. FAO, Rome. 
OECD/FAO, 2007. Agricultural Outlook 2007-2016. FAO, Rome.

OECD/IEA, 2007. Bioenergy Project Development \& Biomass Supply. IEA, Paris.

OECD/FAO, 2008. Agricultural Outlook 2008-2017. FAO, Rome.

Podobnik, B., 2006. Global Energy Shifts: Fostering Sustainability in a Turbulent Age. Temple University Press, Philadelphia, PA.

Prado, C.G., 2000. Starting with Foucault: An Introduction to Genealogy. Westview Press, Boulder, CO.

Torfing, J., 1999. New Theories of Discourse: Laclau, Mouffe, Žižek. Blackwell Publishers, Oxford, UK.

Walter, A., Rosillo-Calle, F., Dolzan, P.B., Piacente, E., Borges da Cunha, K., 2007. Market Evaluation: Fuel Ethanol. Task 40: Sustainable Bio-energy Trade - Securing Supply and Demand. IEA Bioenergy, UNICAMP, Brazil \& UK.

WEC/FAO, 1999. The Challenge of Rural Energy Poverty in Developing Countries. World Energy Council, London. 